\title{
XXVII. Method of raising a loaded cart when the horse in the shafts has fallen
}

\author{
Mr. Benjamin Smith
}

To cite this article: Mr. Benjamin Smith (1811) XXVII. Method of raising a loaded cart when the horse in the shafts has fallen, Philosophical Magazine Series 1, 38:160, 117-119, DOI: $10.1080 / 14786441108638616$

To link to this article: http://dx.doi.org/10.1080/14786441108638616

册 Published online: 27 Jul 2009.

Submit your article to this journal $\sqsubset \pi$

Џ Article views: 2

Q View related articles $\sqsubset$ 


\section{Reference to the Drawing of Mr. Moult's Filtering Appa- ratus, Fig. 1. PI. IV.}

AA is the cistern containing the water to be filtered; the filtering-stone $B$ is suspended in the cistern by a ring around the inside of it, which catches the projecting part of the stone; the water in the cistern filters through into the stone. $D$ is a syphon which conveys the filtered water from the inside of the stone into a cistern $\mathrm{E}$, which is the reservoir for clean water. $d$ a cock to draw it off as it is wanted. By this mode of filtration the impurities of the water are deposited in the bottom of the cistern $A$, instead of being left in the bottom of the stone as in the usual mode.

XXVII. Method of raising a loaded Cart when the Horse in the Shafts has fallen. By Mr. Benjamin SMith*.

Sir, I have taken the liberty of sending you a model with a brief explanation of the utility of my invention, in order that it may be laid before the Society instituted for the Encouragement of Arts, \&c. to whose comprehensive judgement and abilities I with great deference submit it for their determination, whether they think it likely to be attended with the success and ntility which I flatier myself it deserves. From the simplicity of the construction and the trivial expense attending it, I presume there will be no bar to its universal adoption. I respectfully submit it to the discernment and decision of the Society, who will, I am convinced, give it all the merit and approbation it may deserve.

The reason which prompted me to undertake this business is, the having seen a horse which had fallen down under the immense weight of a heavy loaded cart, where it lay for a considerable time in that painfin and dangerous situation, which naturally excited compassion even in the most obdurate heart. Every person frequenting the streets of this metropolis must have winessed sumlar scenes; and indeed it surprises me that long betore now sume expedients have not been publicly suggested to remove the mischief arising from such occurrences, considering the great encouragement that is given in this enlightened age to all useful improvements.

* From Transactions of the Society for the Enrotragement of Arts, Manufacures, and Commerce, for 180 . The Society voted fiften guineas to Mr. Benjamin smith for this communication. 
Having conversed on this subject with persons who possess considerable knowledge of horses, and who constantly employ these noble animals, I find that horses remaining so long as they usually do in such improper positions, and from being often dragged a considerable distance by fruitless endeavours to raise them, are much endangered in their health and lives, and that their situation upon the stones is more prejudicial than the injury received by the fall.

I flatter myself that my method will be found to raise the whole weight of the cart, and a considerable part of that of the horse, in the sbort space of three or four minutes from the moment of the accident, by means simple and useful, and within the reach of the meanest capacity to execute; and that the whole apparatus will not cost above fifty shillings, and will last many years. Requesting your kind attention,

$$
\begin{aligned}
& \text { I am, sir, } \\
& \text { Your most obedient servant, }
\end{aligned}
$$

No. 11, Turnham-Place, Curtain-Road, Shoreditch, London, Dec. 13, 1809.

Benjamin Smith.

To C. Taylor, M.D. Sec.

\section{Advantages derivale from this Invention.}

1.-The invention is of itself so simple, and the operation so conspicuous at the first view, that the whole process may be easily comprehended and execured.

2. - The apparatus may be fitted with little difficulty to any cart now in use for heavy loads, such as bricks, coals, corn, or the like.

3.- The chains which lead from the uprights at the back part of the cart to the fore part of it on each side are for the purpose of taking the purchase therefrom, and making the back part of the cart act as a lever at the time the horses are drawing behind, which without fail, with the strength of one, two or three horses fastened there to raise the one which is down in the shafts, will instantly assist him to get upon bis feet.

4.- The number of horses to draw a cart are usually in proportion to the weight contained therein; therefore supposing three harses are employed to draw it, and the shafthorse falls, the carman tias only to unhook the two leaders and then book them to the short chain at each side of the back of the cart, and with their strength the fallen horse will be so relieved from the weight as to raise himself without further assistance. 
5.-The same principle may be applied in different ways from what $I$ have shown in the model; for instance, another mode may be adopted by framing the tail-board of the cart strong enough to bear the purchase, and with the use of the two side-chains above mentioned it may be made to answer the purpose.

Another plan, though more expensive, is by obtaining two wrought-iron uprights to be fixed as substitutes for the truss-staffs at the back part of the cart, with a hole in the top of each to receive an iron rod, which is occasionally to be introduced, reaching from one side of the cart to the other, connecting the two uprights together; when in action the two side-chains to be used as in other cases.

Reference to the Drawing of Mr. Smith's Method of raising up a Horse when fallen dow'n in the Shafts of a loaded Cart, Fig. 2. Pl. IV.

$A$ is the whecl, and $B$ the shafts of a cart, such as is used in Loudon; $c$ the side-rails; at the end of the body an iron stancheon or truss-staff, $a$, is fixed by a hinge at the lower end, and at the upper end it is supported by a chain $b$, extended from the fore part of the body of the cart: this diagonal chain forms a firm support to the stancheon. This is all the addition made to the common cart, and is used in the event of the shaft-horse falling. by hooking the traces of the other horses to a chain $d$, also fixed to the stancheon: the power of these horses, applied at this height above the fulcrum, will have a great purchase to elevate the shafts and set the fallen horse at liberty, as is evident from an inspection of the figure. The stanchern moves on a joint on its lower end, and the oblique chain unhooks at $b$; the end can be connected with a short piece of chain $e$ fastened to the last of the side-rails; the stancheon now takes the position of the dotted lines $f$, and the short chain which hangs down perpendicular from the end of it, may he taken hold of by any number of men, to weigh upon and raise the cart iu cases where the horses cannot conveniently be applicd; the men will in this manner have much greater effect than merely (as is the common practice) weighing on the hind part of the cart.

When the chain is completely detached, and the stan. cheon suffered to hang down perpendicularly, it forms a prop to support the cart steady whilst it is unloaded. It should be observert, that though only one stancheon appears in the figure, there are in fact two, one being placed on each side of the cart. 
Mr. Moults Filtering Apparatus.

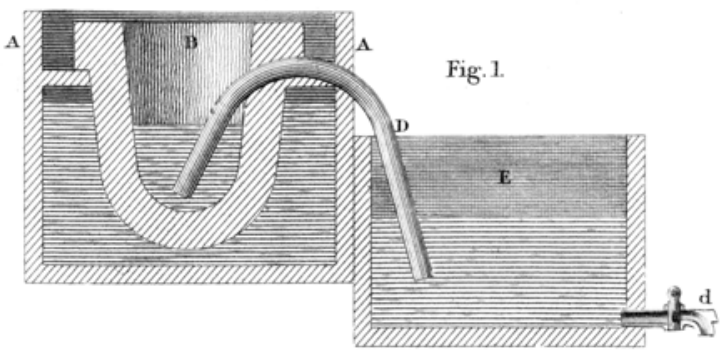

Mr. Smith's method of relieving a Horse which has fallen in the shaft of a loaded Cart.

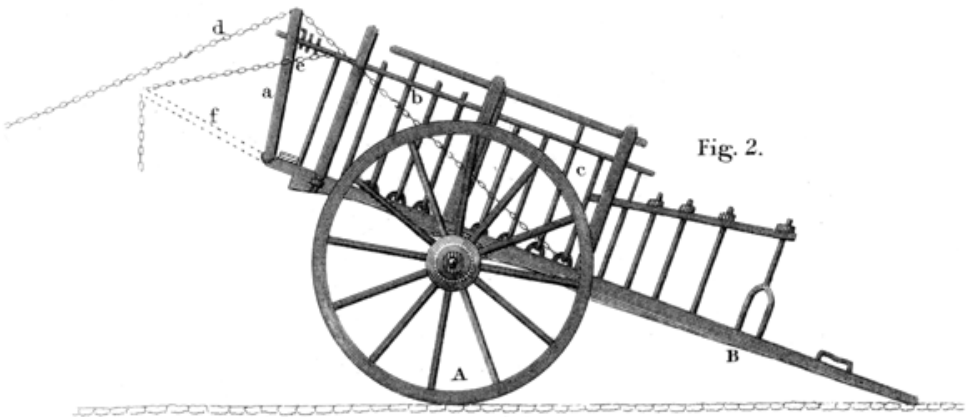

M. Taylor's dir Exhauster for Mines.

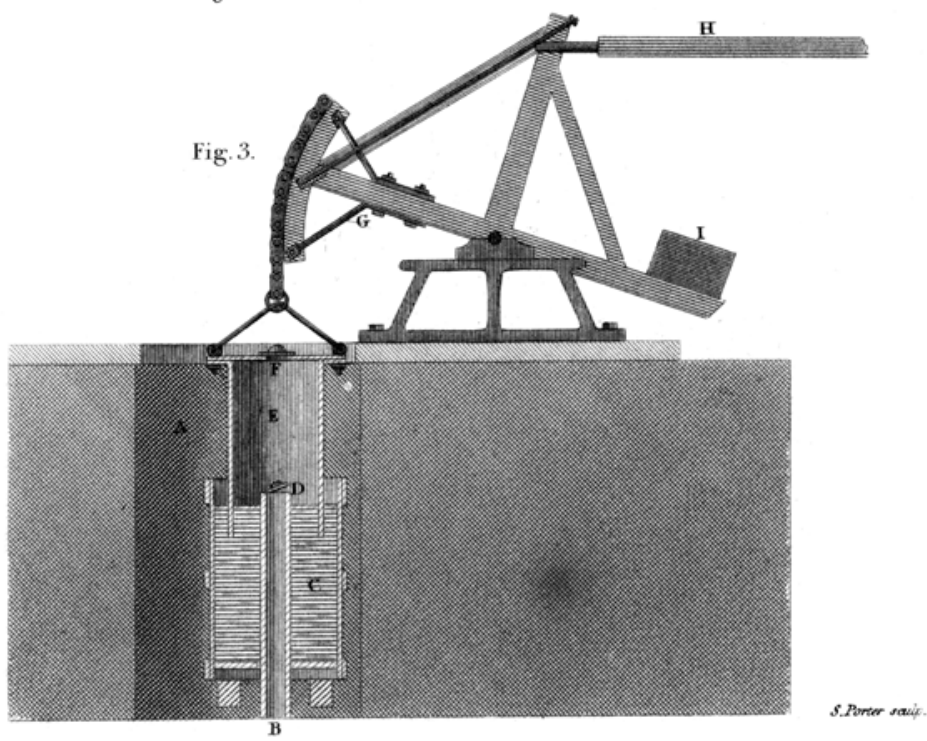

